\title{
The Development of Writing Folk Poetry Teaching Material According to the Materials Expert Team with Copy the Master Technique for Seventh Grade Student of Junior High School 1 Rantau Selatan, In Labuhan Batu District, Indonesia
}

\author{
Tetty Matanari ${ }^{1}$, Syahnan Daulay ${ }^{2}$, Malam Lubis ${ }^{2}$ \\ ${ }^{I}$ Master Student in State University of Medan (Unimed), Medan, Indonesia \\ ${ }^{2}$ Lecturer in State University of Medan (Unimed), Medan, Indonesia \\ tettymatanari@gmail.com
}

\begin{abstract}
The development of a teaching material must be based on the analysis of student needs. Development of teaching materials have to be able to answer or solve problems or difficulties in learning. This study aims to know the development of writing folk poetry teaching material according to the materials expert team with copy the master technique for seventh grade student of junior high school 1 Rantau Selatan, in Labuhan Batu District. This study was conducted by using Probability Sampling technique. The result shows that all teachers and students need modules in the learning process. Teaching material products developed in folk poetry writing materials with copy the master learning technique for seventh grade students of junior high school 1 Rantau Selatan meet the requirements and are appropriate to use based on the validation of material experts and design experts.
\end{abstract}

Keywords : development of writing folk poetry; teaching material; copy the master technique.

\section{Introduction}

The textbook used in Junior High School 1 of Rantau Selatan is an Indonesian textbook, a companion to Indonesian MGMP teacher textbooks in Labuhan Batu District. It is said as a companion book, in fact the textbook is the only textbook for students and teachers of seventh grade in Junior High School 1 of Rantau Selatan without any other guidebooks such as textbooks, worksheets, learning modules, and others.

The essence of textbooks is to provide information and material for students. Assessment of learning outcomes and curriculum is measured by achieving competence. The success of the curriculum is defined as the achievement of competencies designed in curriculum documents by all students. Thus it can be interpreted, the textbook used by the teacher in teaching its contents must be in accordance with the basic competencies to fit the assessment of the learning outcomes demanded by the curriculum. It is also in accordance with the principles of the curriculum that is consistency in determining the material in a teaching material that must be in accordance with basic competencies (Ministry of National Education, 2008).

Local folk poetry is a national cultural heritage that we must maintain. If it is not maintained from generation to generation, it is feared that the folk's poetry will become extinct in line with the times. As the opinion of Syahnan Daulay, et al cited from International Journal of Language and Linguistics, volume 3. Issue 6, November 2015 "the consequences of the use of language with all the supporting factors led to a language to survive and thrive, while disloyalty towards language speakers so switching to another language led to a shift in the language. Language shift can also cause these languages become extinct or endangered. A language can survive if it remains a process of continuous transmission from one generation to the next".

In addition to the above, according to Putri Rosanna Rizal as an Indonesian language teacher for class VII in Junior High School 1 of Rantau Selatan, if students are not taught to 
write local folk poetry students certainly have not been able to write local folk poetry well, unable to express ideas, unable to make verse, unable to make content, not even able to write anything. The same thing was also expressed by Deni Ari Indra Gumilar, in his research journal about efforts to improve the writing of pantun learning for students in Junior High School of Darul Falah for Class VII, The information was found that (1) students tend to feel confused to start writing rhymes between sampiran and content; (2) most of the students do not yet know the easy technique of writing pantun; (3) students also difficult to find ideas to equate the rhyme between verse and content; (4) most students when assigned to write pantun, they only write down the existing pantun; (5) students tend to master the pantun of young people compared to other types of pantun such as advice or religious pantun; (6) most students get values under the KKM.

\section{Review of Literatures}

\subsection{Teaching Materials}

Abidin (2014: 63) argues that teaching materials or instructional material generally consist of knowledge, skills, and attitudes that students must learn in order to achieve predetermined competency standards. In detail, the types of learning material consist of knowledge (facts, concepts, principles, and procedures), skills, and attitudes or values. According to Kemp, what is meant by teaching material is a combination of knowledge (facts and detailed information), skills in the form of steps, procedures, conditions, and roles (Muslih, 2010: 206). Teaching materials can be defined as systematic descriptions related to the exercises and techniques used in classroom teaching. These include: textbooks, audiovisual packages, games, and other activities used in classroom learning (Brown, 1996).

Based on this understanding, it can be concluded that teaching materials are all materials (both information, tools, and texts) that are systematically arranged learning in accordance with the competencies to be achieved which are a combination of aspects of knowledge, skills, and attitudes or values. For example textbooks, modules. Handouts, worksheets, etc. Teaching materials are a very important element that must get the attention of teachers in the implementation of teaching and learning activities in the classroom so that the desired learning objectives can be achieved. With the teaching materials, students can learn the things needed in an effort to achieve learning goals. Teaching materials are considered important both for students and teachers because the teaching material becomes the concept of knowledge, skills, and attitudes that function in learning.

\subsection{Development of Teaching Materials}

The development of teaching materials is closely related to the development of syllabus, in which there are core competencies and basic competencies, subject matter, learning experience, methods, evaluation, and learning resources. In line with the development of the syllabus, the learning material that will be developed should still pay attention to the achievement of core competencies and basic competencies.

Development of teaching materials is the process of selecting, adapting, and making teaching materials based on a certain frame of reference (Nunan, 1991). The development of teaching materials is the process of making teaching materials in the form of training and learning techniques used in classroom teaching. This includes textbooks, audiovisual packages, games, and other activities used in teach (Brown, 1996). 
The development of a teaching material must be based on the analysis of student needs. There are a number of reasons why it is necessary to develop teaching materials, as mentioned by the Directorate of Upper School Development (2008: 8-9) as follows.

a. Availability of materials according to the demands of the curriculum, meaning learning materials developed must be in accordance with the curriculum.

b. Characteristics of the target, It means that the teaching materials developed can be adjusted to the characteristics of students as targets, these characteristics covering social, cultural, geographical and developmental environments students.

c. Development of teaching materials must be able to answer or solve problem or difficulties in learning.

\subsection{Modules as Teaching Materials}

Syamsudin (2005: 168) suggests that modules are printed teaching materials designed to be studied independently by learning participants. Modules are also called media for independent learning because they have been equipped with instructions for self-study. It means that readers can conduct learning activities without the presence of the teacher directly. A similar view was also expressed by Andi Prastowo (2012: 106), a module is a teaching material that is structured systematically in a language that is easily understood by students, according to their age and level of knowledge so that they can learn independently with minimal guidance from educators.

Hamdani (2011: 219) suggests that the module is a learning tool that contains material, methods, limitations of subject matter, instructions for learning, training, and evaluating methods designed systematically and interestingly to achieve the expected competencies and can be used independently.

Based on several opinions outlined, it can be concluded that the module is one form of printed teaching material that is designed structurally and systematically to assist the learning process, can be used independently by the learning participants without the presence of the instructor directly. Therefore, students can learn according to their respective speeds.

\subsection{Folk Poetry}

E. Kosasih and Endang Kurniawan (2018: 283) suggest that folk poetry (old poetry) is a type of poetry that develops in people's daily lives; as a tradition of the local community. Folk poetry is spread orally. The form is generally standard or bound by various provisions, such as the number of lines per verse, the number of syllables in each array, or the pattern of the receipt. Danandjaja (1997: 46) argues that folk poetry is people's literature that has a certain form, usually occurs from several lines of sentence, some based on spells, some based on short lengths of syllables, weak sound pressure, or only based on rhythm. Jan Harold Brunvand (in Danandjaya, 1984: 21) says folk poetry is oral folklore. The specificity of this oral folklore genre is that the sentence is not free phrase, but is a fix phrase. Folk poetry is usually used for folk art activities which are a part of folk culture that are offered, delivered, disseminated in oral form.

From the study above, it can be concluded that folk poetry (old poetry) is a people's literature that develops in everyday life as a tradition that has a certain form, number of words, number of lines in each stanza, repetition of words, bounded sentences, and usually used in folk art activities which are part of folk culture that are offered, delivered, and disseminated in oral form. 


\section{Research Methods}

This study was conducted in Junior High School 1 Rantau Selatan which located in Rantauprapat City, Labuhanbatu District. The study was held from April to June 2018. The subjects in this study were seventh grade students of Junior High School 1 Rantau Selatan, Rantauprapat, Labuhanbatu District. Sources of sample school data include students and teachers. The number of students used as the subject of data acquisition amounted to 32 students. While the teacher numbered two people. Sampling is done by Probability Sampling technique (Sugiyono, 2010: 218).

\section{Discussion}

The questionnaire search results found that $100 \%$ of the teachers and students stated that they needed teaching materials using copy the master technique, especially in the material of folk poetry writing in the learning process to be more effective and to be used by students as an individual learning tool. Data needs analysis can be seen in table 4.1. Following.

Table 1. Data Needs Analysis

\begin{tabular}{|c|c|c|c|c|c|c|}
\hline \multirow{2}{*}{ No } & \multirow{2}{*}{ Question } & \multirow{2}{*}{ Answer } & \multicolumn{3}{|c|}{ Frequency } & \multirow{2}{*}{ Percentage } \\
\hline & & & Teacher & Student & Total & \\
\hline \multirow[b]{2}{*}{1} & \multirow{2}{*}{$\begin{array}{l}\text { Get to know the } \\
\text { teaching materials in } \\
\text { the form of modules }\end{array}$} & Yes & 2 & 3 & 5 & $14,70 \%$ \\
\hline & & No & - & 29 & 29 & $85,30 \%$ \\
\hline \multirow[b]{2}{*}{2} & \multirow{2}{*}{$\begin{array}{l}\text { Using teaching } \\
\text { materials in the form } \\
\text { of modules }\end{array}$} & Yes & - & - & - & - \\
\hline & & No & 2 & 32 & 34 & $100 \%$ \\
\hline \multirow[b]{2}{*}{3} & \multirow{2}{*}{$\begin{array}{l}\text { Requires teaching } \\
\text { materials in the form } \\
\text { of modules in writing } \\
\text { folk poetry teaching } \\
\text { material by copy the } \\
\text { master technique }\end{array}$} & Yes & 2 & 32 & 34 & $100 \%$ \\
\hline & & No & - & - & - & - \\
\hline
\end{tabular}

Based on the results of the analysis of the needs of teachers and students it can be concluded that the development of teaching materials is needed by teachers and students in the learning process to improve the quality of learning. Next, the researchers conducted a teaching material plan in the form of a module of local folk poetry material that is Malay folk poetry in Labuhanbatu with copy the master technique. Then, the teaching materials developed were validated by material experts and learning design experts. After being validated, 3 people tested the product, a small group of 9 people, and a limited field group of 32 people and then revised to determine the feasibility of the module. Thus the teaching materials obtained are valid.

The feasibility of teaching materials will explain the four components of feasibility which include: 1) the feasibility of content, 2) the feasibility of language, 3) the feasibility of presentation, and 4) the feasibility of graphics. The feasibility of teaching materials is obtained after going through the validation process by material experts and learning design experts. The average gain in the feasibility of teaching materials in the category is very good and worthy of 
being used as additional teaching materials in the teaching and learning process in the classroom. Data is obtained as follows.

1) Content Feasibility

Feasibility of content consists of four components, namely a) the suitability of the material with KI and KD the total percentage of $95.83 \%$ in the criteria of "very good", b) the accuracy of the material whose total percentage is $89.28 \%$ with the criteria "very good", c) proficiency material with a total percentage of $90 \%$ with the criteria of "very good", d) encourage curiosity with a total percentage of $100 \%$ with the criteria of "very good"

2) Language Feasibility

Language feasibility consists of five sub-components, namely a) straightforward with a total percentage of $87.5 \%$ eligibility including the criteria of "very good", b) communicative with a total percentage of $87.5 \%$ with criteria "very good", c) dialogue and interactive with total percentage of $100 \%$ with the criteria of "very good", d) conformity with the development of students with a total percentage of $75 \%$ in the criteria of "good", e) conformity with the rules of language with a total percentage of $100 \%$ with the criteria "very good", and f ) the use of terms, symbols or icons with a total percentage of $87.5 \%$ in the criteria of "very good".

3) Feasibility of Presentation

Feasibility of presentation consists of four components, namely, a) presentation techniques with a total percentage of $93.75 \%$ with the criteria of "very good", b) supporting presentation with a total percentage of $93.75 \%$ with criteria "very good", c) presentation of total percentage learning $87.5 \%$ with the criteria of "very good", d) coherence and plot flow of thought with a total percentage of $87.5 \%$ with the criteria of "very good".

4) Feasibility of Graphics

Feasibility of graphics consists of three sub-chapters which include a) the size of teaching materials with a total percentage of $87.5 \%$ in the criteria of "very good", b) design of the cover of teaching materials with a total percentage of $91.66 \%$ with the criteria "very good", c) design content of teaching materials with a total percentage of $92.18 \%$ in the criteria of "very good".

Validation of the product is intended to determine the opinions of material experts about the feasibility of content, the feasibility of presentation, and language. This validation was carried out by Prof. Dr. Khairil Ansari, M.Pd. who is a lecturer at Medan State University and an expert in the field of Indonesian language and literary education and Tri Gestawaty Siregar, M.Pd., who is an Indonesian language teacher at Junior High School 1 Rantau Selatan and also a lecturer in Indonesian language and literature education in UNIVA Labuhanbatu. The assessment was carried out to obtain information on the quality of the teaching materials developed that were used to improve the quality of learning in Junior High School 1 Rantau Selatan on folk poetry material.

The results of the validation and assessment by the material experts in each aspect of the overall assessment are determined by the average score of the respective criteria. The results of the assessment were analyzed to determine whether or not appropriate teaching materials were developed in the form of modules in folk poetry writing material using copy the master technique to use. The average percentage of the results of the assessment by material experts was assessed based on aspects and indicators of assessment. 
The results of the validation of the material experts obtained are then classified and converted into classifications in the form of percentages, then will be made in the form of negative data with reference to the following criteria table:

Table 2. Levels of Trends in Material Expert Assessment of Learning Teaching Materials

\begin{tabular}{|l|l|l|}
\hline No & Answer & Score Range \\
\hline 1 & Unsatisfied & $0 \% \leq \mathrm{X} \leq 40 \%$ \\
\hline 2 & Not good & $41 \% \leq \mathrm{X} \leq 60 \%$ \\
\hline 3 & Good & $61 \% \leq \mathrm{X} \leq 80 \%$ \\
\hline 4 & Very Good & $81 \% \leq \mathrm{X} \leq 100 \%$ \\
\hline
\end{tabular}

Table 3. Material Expert Assessment of Writing Folk Poetry Teaching Material by Copy the Master Technique for Feasibility of Content (First Meeting)

\begin{tabular}{|c|c|c|c|}
\hline No & Assessment Indicator & $\begin{array}{l}\text { Average } \\
\text { Score }\end{array}$ & Criteria \\
\hline \multicolumn{2}{|c|}{ A. Compatibility of material with KI and KD } & 75 & Good \\
\hline & 1. Completeness of material & 87,5 & Very Good \\
\hline & 2. Material breadth & 75 & Good \\
\hline & 3. Depth of material & 62,5 & Good \\
\hline \multicolumn{2}{|r|}{ B. Material accuracy } & $\mathbf{7 8 , 5 7}$ & Good \\
\hline & $\begin{array}{l}\text { 4. Accuracy of the concept of folk } \\
\text { poetry and the master copy technique }\end{array}$ & 75 & Good \\
\hline & 5. Accuracy of data and facts & 87,5 & Very Good \\
\hline & 6. Accuracy of folk poetry examples & 75 & Good \\
\hline & 7. Accuracy of images and illustrations & 75 & Good \\
\hline & 8. Accuracy of terms & 87,5 & Very Good \\
\hline & $\begin{array}{l}\text { 9. Accuracy of notations, symbols and } \\
\text { icons }\end{array}$ & 75 & Good \\
\hline & 10. Accuracy of references & 75 & Good \\
\hline \multicolumn{2}{|r|}{ C. Proficiency of Material } & 72,5 & Good \\
\hline \multicolumn{2}{|r|}{$\begin{array}{l}\begin{array}{c}\text { 11. Compatibility of material with the } \\
\text { daily lives of students }\end{array} \\
\end{array}$} & 75 & Good \\
\hline & 12. Examples and cases in everyday life & 75 & Good \\
\hline & $\begin{array}{l}\text { 13. Pictures and illustrations in everyday } \\
\text { life }\end{array}$ & 75 & Good \\
\hline & $\begin{array}{l}\text { 14. Use examples contained in everyday } \\
\text { life }\end{array}$ & 75 & Good \\
\hline & 15. Library update & 62,5 & Good \\
\hline \multicolumn{2}{|c|}{ D. Encourage curiosity } & 68,75 & Good \\
\hline & 16. Encourage curiosity & 75 & Good \\
\hline & 17. Creating the ability to ask questions & 62,5 & Good \\
\hline \multicolumn{2}{|c|}{ Average Total } & $\mathbf{7 3 , 7 1}$ & Good \\
\hline
\end{tabular}

Furthermore, the data from the validation of the material experts on aspects of language assessment can be seen in table 4.4. 
Table 4. Material Expert Assessment of Writing Folk Poetry Teaching Material by Copy the Master Technique for Language Feasibility (First Meeting)

\begin{tabular}{|c|c|c|c|}
\hline Sub Component & Indicator & $\begin{array}{l}\text { Average } \\
\text { Score }\end{array}$ & Criteria \\
\hline \multicolumn{2}{|l|}{ A. Straightforward } & 75 & Good \\
\hline \multirow[t]{3}{*}{ (n) } & $\begin{array}{l}\text { 1. Accuracy of sentence } \\
\text { structure }\end{array}$ & 75 & Good \\
\hline & 2. Effectiveness of sentences & 75 & Good \\
\hline & 3. Stiffness of terms & 75 & Good \\
\hline B. Communicative & $\begin{array}{l}\text { 4. Understanding of messages } \\
\text { or information }\end{array}$ & 87,5 & Very Good \\
\hline \multicolumn{2}{|c|}{ C. Dialogical and interactive } & 68,75 & Good \\
\hline \multicolumn{2}{|c|}{\begin{tabular}{|l|lll|} 
5. Motivating ability of \\
students
\end{tabular}} & 75 & Good \\
\hline & $\begin{array}{l}\text { 6. The ability to encourage } \\
\text { critical thinking }\end{array}$ & 62,5 & Good \\
\hline \multicolumn{2}{|c|}{ D. Conformity with student development } & 75 & Good \\
\hline 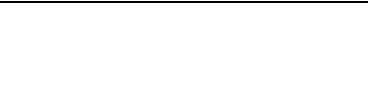 & $\begin{array}{l}\text { 7. Conformity with intellectual } \\
\text { development of educators }\end{array}$ & 75 & Good \\
\hline & $\begin{array}{l}\text { 8. Conformity with the level of } \\
\text { emotional development of } \\
\text { the educator }\end{array}$ & 75 & Good \\
\hline \multicolumn{2}{|c|}{ E. Conformity with linguistic rules } & 75 & Good \\
\hline & 9. Accuracy of grammar & 75 & Good \\
\hline & 10. Accuracy of spelling & 75 & Good \\
\hline \multicolumn{2}{|c|}{ F. Use of terms, symbols, or icons } & 75 & Good \\
\hline & $\begin{array}{l}\text { 11. Consistency in the use of } \\
\text { terms }\end{array}$ & 75 & Good \\
\hline & $\begin{array}{l}\text { 12. Consistency in the use of } \\
\text { symbols or icons }\end{array}$ & 75 & Good \\
\hline \multicolumn{2}{|l|}{ Average Total } & 76,04 & Good \\
\hline
\end{tabular}

Then the validation data from the material expert on the feasibility of presentation can be seen in table 5 .

Table 5. Material Expert Assessment of Writing Folk Poetry Teaching Material by Copy the Master Technique for Feasibility of Presentation (Meeting I)

\begin{tabular}{|l|l|l|l|}
\hline No & Indicator & $\begin{array}{l}\text { Average } \\
\text { Score }\end{array}$ & Criteria \\
\hline A. Presentation Techniques & $\mathbf{7 5}$ & Good \\
\hline & $\begin{array}{l}\text { 1. Systematic consistency in } \\
\text { serving in learning activities }\end{array}$ & 75 & Good \\
\cline { 2 - 4 } & 2. The dullness of the concept & 75 & Good \\
\hline \multicolumn{2}{|l|}{ B. Supporting Presentation } & $\mathbf{7 6 , 5 6}$ & Good \\
\hline & $\begin{array}{l}\text { 3. Examples of questions in } \\
\text { each learning activity. }\end{array}$ & 75 & Good \\
\hline
\end{tabular}




\begin{tabular}{|c|c|c|c|}
\hline & $\begin{array}{l}\text { 4. Practice questions at the end } \\
\text { of each learning activity }\end{array}$ & 75 & Good \\
\hline & $\begin{array}{l}\text { 5. Key answers to practice } \\
\text { questions }\end{array}$ & 75 & Good \\
\hline & $\begin{array}{l}\text { 6. Feedback on practice } \\
\text { questions }\end{array}$ & 75 & Good \\
\hline & 7. Introduction & 75 & Good \\
\hline & 8. Glossary & 75 & Good \\
\hline & 9. Bibliography & 75 & Good \\
\hline & 10. Summary & 87,5 & Very Good \\
\hline $\begin{array}{l}\text { C. Presentation of } \\
\text { Learning }\end{array}$ & $\begin{array}{l}\text { 11. Conformity of the master } \\
\text { copy technique with folk } \\
\text { poetry learning }\end{array}$ & 75 & Good \\
\hline D. Coherence ar & id clutter of thought & 68,75 & Good \\
\hline & $\begin{array}{l}\text { 12. Linkages between learning } \\
\text { activities / sub-learning } \\
\text { activities / paragraphs } \\
\end{array}$ & 62,5 & Good \\
\hline & $\begin{array}{l}\text { 13. Integrity of meaning in } \\
\text { learning activities / sub- } \\
\text { learning activities } \\
\text { paragraphs. }\end{array}$ & 75 & Good \\
\hline Average Total & & 73,82 & Good \\
\hline
\end{tabular}

The average percentage results from the aspect of content eligibility, language feasibility, and the feasibility of presenting at the first meeting can be seen in table 6 below.

Table 6. Percentage of Material Expert Assessment (First Meeting)

\begin{tabular}{|l|l|l|l|}
\hline No & Sub Component of Assessment & Average Score & Criteria \\
\hline 1 & Feasibility of content & 73,71 & Good \\
\hline 2 & Language feasibility & 76,04 & Good \\
\hline 3 & Feasibility of presentation & 73,82 & Good \\
\hline Average Total & $\mathbf{7 4 , 5 2}$ & Good \\
\hline
\end{tabular}




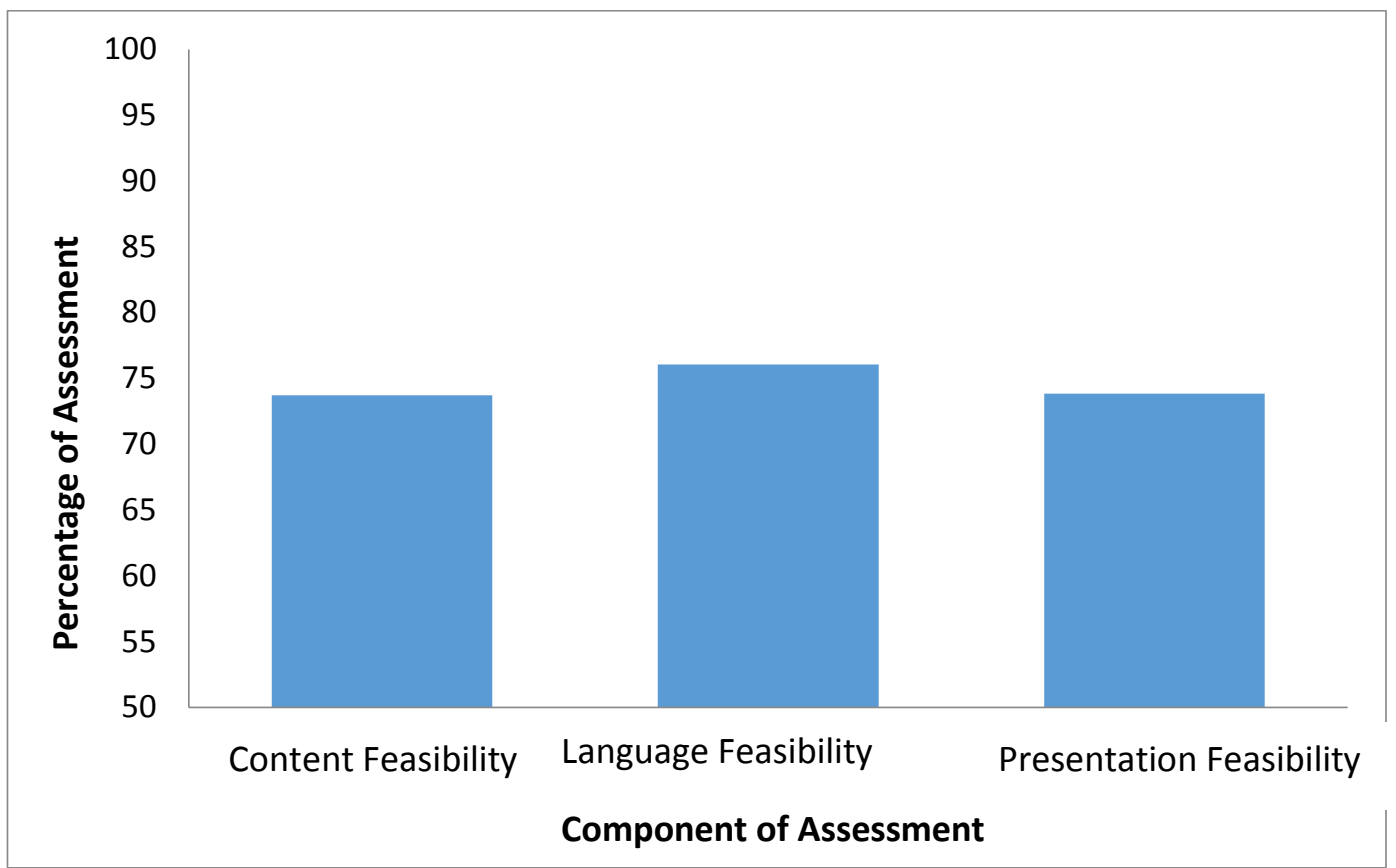

Figure 1. Diagram of the Material Validation Results (First Meeting)

Suggestions of material expert validators at meeting I both in writing and verbally in general are listed in table 7 .

Table 7. Suggestions from the Material Validator

\begin{tabular}{|l|l|}
\hline No. & Suggestion \\
\hline 1. & $\begin{array}{l}\text { Try the assessment points for each lesson containing Higher Order Thinking } \\
\text { Skills (HOTS). }\end{array}$ \\
\hline 2. & $\begin{array}{l}\text { Revised the evaluation points for each learning that invites students to think } \\
\text { and produce creativity. }\end{array}$ \\
\hline 3. & $\begin{array}{l}\text { The material presented is less profound so students get to know the poetry of } \\
\text { the local people. }\end{array}$ \\
\hline 4. & Expand the references used. \\
\hline 5. & $\begin{array}{l}\text { Difficult words in learning material should be made meaning that students } \\
\text { understand what they are learning. }\end{array}$ \\
\hline
\end{tabular}

To improve teaching materials so that they are worthy of being tested in the field in accordance with the advice of the material experts listed in table 7 the researcher revised. After the revision was made, material experts reviewed the teaching materials at the meeting II. The results of the material expert's assessment of the appropriateness of the content of teaching materials to write poetry of local folk with copy the master technique can be seen in table 8 below. 
Table 8. Material Expert Assessment of Writing Folk Poetry Teaching Material by Copy the Master Technique for Feasibility of Content (Meeting II)

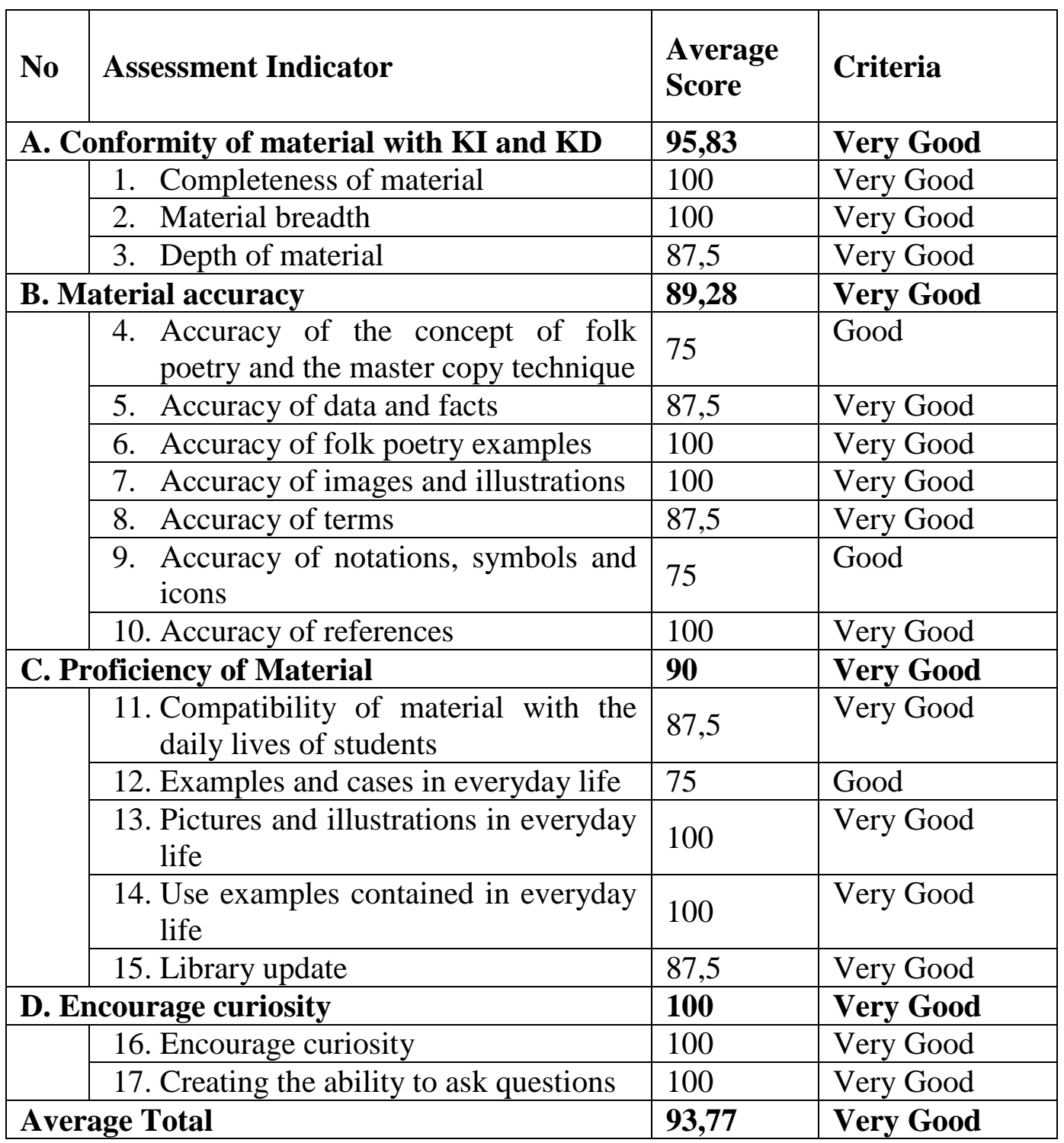

Based on the assessment of meeting II, the results of the percentage of material experts on content eligibility obtained that the sub-component of the assessment of material suitability with KI and KD had an average percentage of $95.83 \%$ with the criteria of "Very Good". The results of the validation of the material suitability sub-component with KI and KD reached the average value of the material developed in teaching materials in accordance with KI and KD, the breadth of material in the teaching material was quite extensive regarding folk poetry material and the depth of the material developed is also in depth or folk poetry material that discussed more deeply than the student textbooks, so the material experts gave a very good assessment of the components of material suitability with KI and KD.

Furthermore, the data from the validation of II meetings by material experts on aspects of language assessment can be seen in table 9 . 
Table 9. Material Expert Assessment of Writing Folk Poetry Teaching Material by Copy the Master Technique for Language Feasibility (Meeting II)

\begin{tabular}{|c|c|c|c|}
\hline Sub Component & Indicator & $\begin{array}{l}\text { Average } \\
\text { score }\end{array}$ & Criteria \\
\hline \multicolumn{2}{|l|}{ A. Straightforward } & 87,5 & Very Good \\
\hline \multirow[t]{3}{*}{ 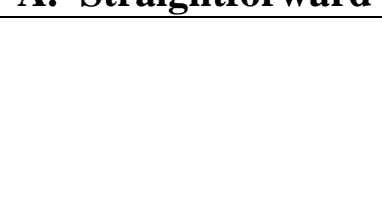 } & $\begin{array}{l}\text { 1. Accuracy of sentence } \\
\text { structure }\end{array}$ & 75 & Good \\
\hline & 2. Effectiveness of sentences & 87,5 & Very Good \\
\hline & 3. Stiffness of terms & 100 & Very Good \\
\hline B. Communicative & $\begin{array}{l}\text { 4. Understanding of } \\
\text { messages or information }\end{array}$ & 87,5 & Very Good \\
\hline \multicolumn{2}{|c|}{ C. A. Dialogical and interactive } & 100 & Very Good \\
\hline & $\begin{array}{lll}\text { 5. } & \begin{array}{l}\text { Motivating ability of } \\
\text { students }\end{array}\end{array}$ & 100 & Very Good \\
\hline & $\begin{array}{l}\text { 6. The ability to encourage } \\
\text { critical thinking }\end{array}$ & 100 & Good \\
\hline \multicolumn{2}{|c|}{ D. Conformity with student development } & 75 & Good \\
\hline \multirow[t]{2}{*}{ (n) } & $\begin{array}{l}\text { 7. Conformity with } \\
\text { intellectual development of } \\
\text { educators }\end{array}$ & 75 & Good \\
\hline & $\begin{array}{l}\text { 8. Conformity with the level } \\
\text { of emotional development } \\
\text { of the educator }\end{array}$ & 75 & Good \\
\hline \multicolumn{2}{|c|}{ E. Conformity with linguistic rules } & 100 & Good \\
\hline & 9. Accuracy of grammar & 100 & Good \\
\hline & 10. Accuracy of spelling & 100 & Good \\
\hline \multicolumn{2}{|c|}{ F. Use of terms, symbols, or icons } & 87,5 & Good \\
\hline & $\begin{array}{l}\text { 11. Consistency in the use of } \\
\text { terms }\end{array}$ & 100 & Good \\
\hline & $\begin{array}{l}\text { 12. Consistency in the use of } \\
\text { symbols or icons }\end{array}$ & 75 & Good \\
\hline \multicolumn{2}{|l|}{ Average Total } & 90 & Good \\
\hline
\end{tabular}

Based on table 9, it shows the assessment of the meeting II material experts assessed the teaching material in the form of a module to write poetry of the local people with copy the master technique which was developed to have language feasibility with a percentage score of $90 \%$ with the criteria of "Very Good". The straightforward sub-component achieves an average value of $87.5 \%$ with the criteria of "very good". This shows that the accuracy of the sentence structure of sentence effectiveness, and the correctness of terms in the teaching materials of writing local people's poetry with the master copy technique are very straightforward, so that the use of teaching materials students do not have difficulty in understanding folk poetry with the master copy technique.

Furthermore, the data from the validation of II meetings by material experts on the feasibility of presentation can be seen in table 10 . 
Table 10. Material Expert Assessment of Writing Folk Poetry Teaching Material by Copy the Master Technique for Feasibility of Presentation (Meeting II)

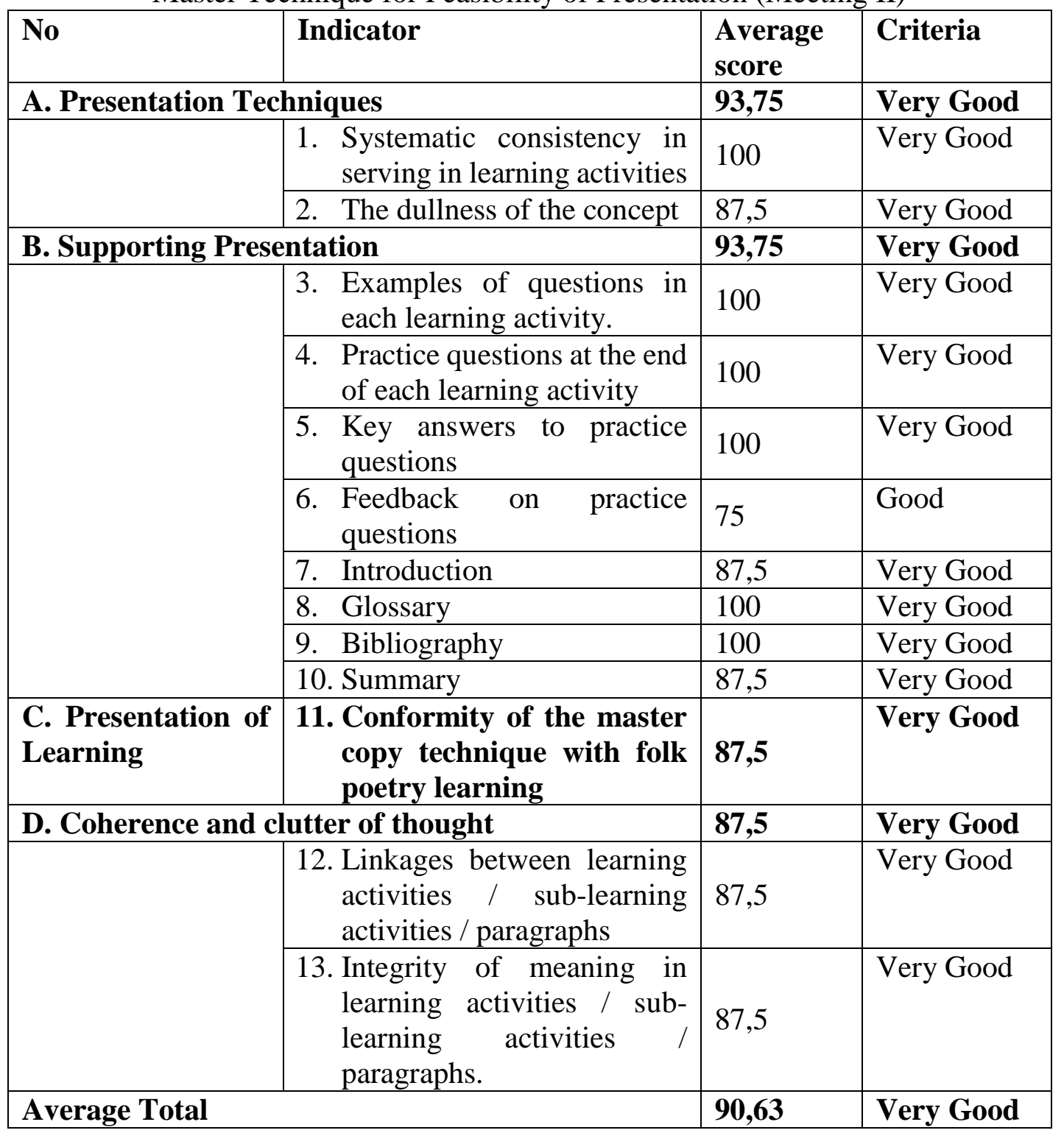

The results of the average percentage from the aspect of content eligibility, language feasibility, and the feasibility of presenting at the second meeting can be seen in table 11 below.

Table 11. Percentage of Material Expert Assessments at Meeting II

\begin{tabular}{|l|l|l|l|}
\hline No & Sub Component of Assessment & Average score & Criteria \\
\hline 1 & Content Feasibility & 93,77 & Very Good \\
\hline 2 & Language Feasibility & 90 & Very Good \\
\hline 3 & Presentation Feasibility & 90,63 & Very Good \\
\hline Average Total & $\mathbf{9 1 , 4 6}$ & Very Good \\
\hline
\end{tabular}




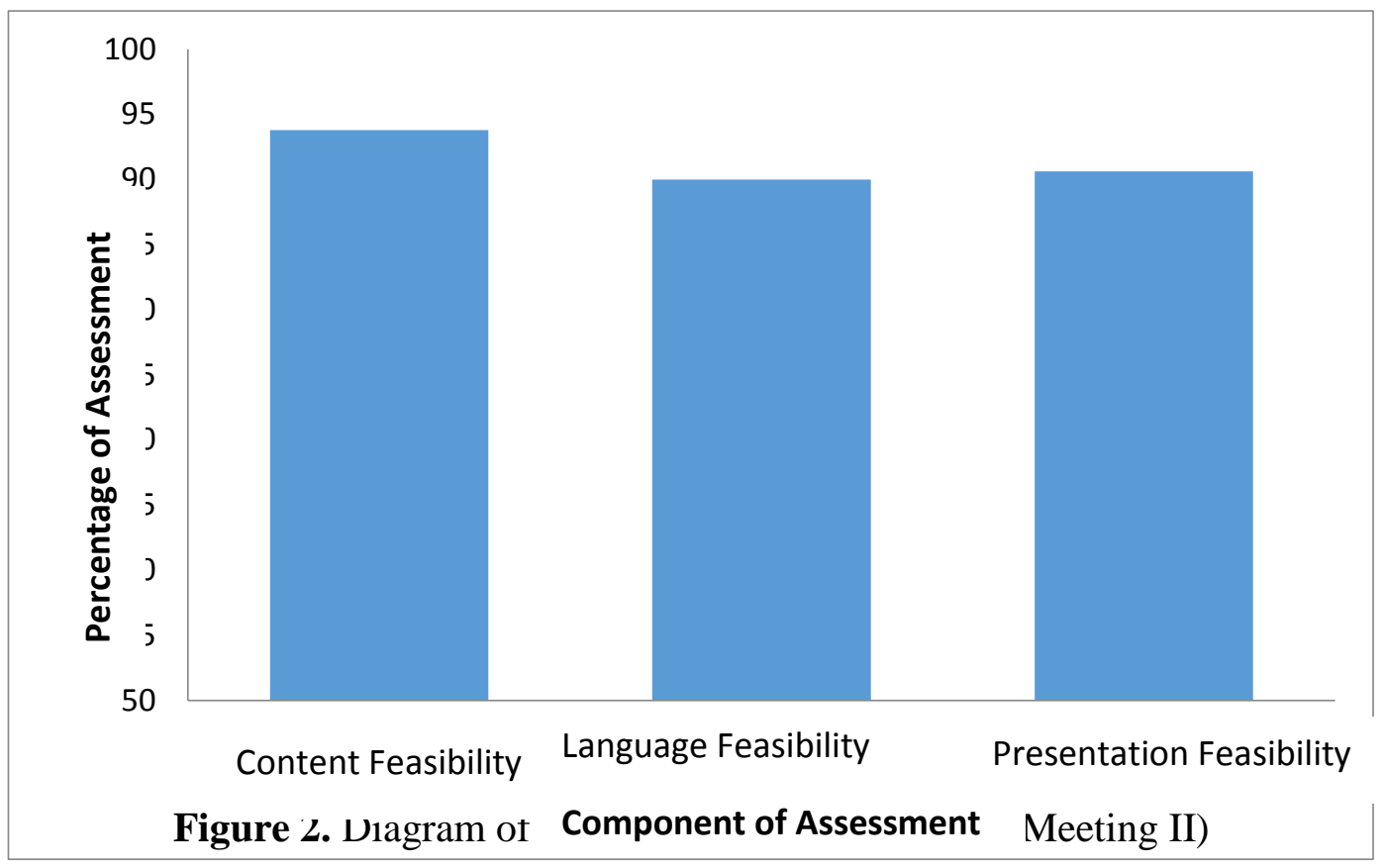

\section{Conclusion}

Needs analysis was carried out to identify the problems of teachers and seventh grade students of Junior High School 1 Rantau Selatan. Based on the description and questions in the form of questionnaires, all teachers and students (100\%) stated that they really needed the folk poetry teaching material in the form of modules. Thus it is stated that all teachers and students need modules in the learning process. Teaching material products developed in folk poetry writing materials with copy the master learning technique for seventh grade students of junior high school 1 Rantau Selatan meet the requirements and are appropriate to use based on the validation of material experts and design experts including the feasibility of teaching material content with an average of $91,77 \%$ of the criteria are very good, the feasibility of language with an average of $90 \%$ on the criteria is very good, and the feasibility of presentation with an average of $90.63 \%$ on the criteria is very good, and the validation of design experts with an average of $85 \%$ on very good criteria.

\section{References}

Abidin, Yunus. 2014. Desain Sistem Pembelajaran dalam Konteks Kurikulum 2013. Bandung : Refika Aditama.

Akmal. 2015. Kebudayaan Melayu Riau (Pantun, Syair, Gurindam). Journal. Tarbiyah and Teacher Education Faculty, UIN Suska Riau.

Arifin, Zainal. 2009. Evaluasi Pembelajaran Prinsip, Teknik, Prosedur. Jakarta: Remaja Rosdakarya.

Arikunto, Suharsimi. 2006. Prosedur Penelitian Suatu Pendekatan Praktik. Jakarta: Rineka Cipta.

Damayanti, Indah. 2014. Pemanfaatan Cerita Rakyat (Folklor) dalam Pengajaran Bahasa Inggris. Journal. FKIP Bengkulu University. 
Budapest International Research and Critics in Linguistics and Education (BirLE) Journal Volume 2, No 3, August 2019, Page: 254-268 e-ISSN: 2655-1470 (Online), p-ISSN: 2655-2647 (Print) www.bircu-journal.com/index.php/birle emails: birle.journal@gmail.com birle.journal.qa@gmail.com

Danandjaja, James. 1994. Folklor Indonesia. Jakarta : Pustaka Utama Grafiti.

Daud, Haron and Siregar, Ahmad Samin. 2004. Mutiara Sastra Malaysia- Indonesia. Medan: USU Press.

Daulay, Syahnan. 2017. Shift and Level of The Threatening of Lubu Siladang Language Extinction. Journal. International Journal of Language Learning and Applied Linguistic World (IJLLALW).

Doyin, Mukh. 2014. Pengembangan Materi ajar Puisi di SD. Journal. Semarang State University.

Effendy Tenas. 2004. Pemakaian Ungkapan dalam Upacara Perkawinan Orang Melayu. Yogyakarta : Adi Cita.

Gumilar, Deni Ari Indra. 2013. Upaya Meningkatkan Pembelajaran Menulis Pantun Melalui Teknik Copy The Master. Journal. Indonesian education University.

Husni Tamrin. 2007. Etnografi Melayu Tradisi dan Modernisasi. Pekanbaru: Suska Press.

H.P, Ahmad and Alek. 2009. Buku Ajar Bahasa Indonesia. Jakarta : FTIK Press (Tarbiyah and Teacher Education Faculty of UIN Syarif Hidayatullah Jakarta.

http;// maskursmkn.files.com/2009/07/teori_modul.pdf.

Johnson, Elaine B. 2010. Contextual Teaching and Learning, Menjadikan Kegiatan BelajarMengajar Mengasyikkan dan Bermakna. Tanpa kota: MLC.

Kementrian Pendidikan dan Kebudayaan Republik Indonesia. 2014. Bahasa Indonesia SMP/MTs Kelas VII. Kemdikbud.

Kosasih, E. and Endang Kurniawan. 2018. Jenis-Jenis Teks. Bandung : Yrama Widya.

Kurnianingtyas, Endah. 2015. Penerapan Teknik Copy The Master untuk Meningkatkan Keterampilan Menulis Cerpen Siswa Kelas VII-B MTS.Darun Najah Petahun Lumajang. Jurnal.

Lubis, Mina Syanti, et al. 2015. Pengembangan Modul Pembelajaran Bahasa Indonesia Berbantuan Peta Pikiran pada Materi Menulis Makalah Siswa Kelas XI SMA/MA. Journal. Padang State University.

Marahimin, Ismail. 2014. Menulis Secara Populer. Jakarta : Pustaka Jaya.

Marahimin, Ismail. 2015. Menulis Secara Populer. Jakarta : Dunia Pustaka Jaya

Masruroh, Ana. 2015. Pengembangan Modul Pembelajaran Menulis Cerpen Berbasis Pengalaman untuk Siswa SMP/MTs. Skripsi. Yogyakarta State University.

Mulyasa. 2010. Implementasi Kurikulum Tingkat Satuan Pendidikan. Jakarta : Bumi Aksara.

Muslich, Masnur. 2010. KTSP (Kurikulum Tingkat Satuan Pendidikan): Dasar Pemahaman dan Pengembangan. Jakarta : Bumi Aksara.

Nursayyidah, Shintia Rizki. 2015. Penerapan Teknik Copy The Master Berbasis Perkembangan Intelektual dalam Pembelajaran Menulis Berita Siswa Kelas VIII. Journal. Indonesian education University.

Prastowo, Andi. 2014. Pengembangan Bahan Ajar Tematik Tinjauan Teoretis dan Praktik. Jakarta: Kencana Prenada Media Group.

Prawiradilaga, Dewi Salma. 2008. Prinsip Desain Pembelajaran: Instructional Design Principles. Jakarta : Kencana.

Putra, Nusa. 2012. Research and Development Penelitian dan Pengembangan : Suatu Pengantar. Jakarta : Raja Grafindo Persada.

Ramadhanti, Dina, et al. 2015. Pengembangan Modul Pembelajaran Menulis Cerpen Berbasis CTL Siswa Kelas IX SMP Negeri 2 Lembah Gumanti Kabupaten Solok. Journal. Padang State University. 
Ratna, Kutha Nyoman. 2004. Teori, Metode, dan Teknik Penelitian Sastra. Yogyakarta : Pustaka Pelajar.

Sanjaya, Wina. 2008. Strategi Pembelajaran Berorientasi Standar Proses Pendidikan. Jakarta : Kencana Prenadamedia Group.

Sayuti, Suminto A, at el. 2009. Modul Menulis Fiksi. Yogyakarta : PBSI FBS UNY.

Sugiyono. 2011. Metode Penelitian Kombinasi (Mixed Methods). Bandung: Alfabeta.

Sugiyono. 2013. Metode Penelitian Pendidikan : Pendekatan Kuantitatif, Kualitatif dan $R$ dan D. Bandung : Alfabeta.

Sugiyono. 2016. Metode Penelitian Pendidikan : Pendekatan Kuantitatif, Kualitatif dan $R$ dan D. Bandung : Alfabeta.

----------. 2013. Metode Penelitian Kuantitatif Kualitatif dan R\&D. Bandung : Alfabeta.

Sulistyorini, Dwi. 2013. Pemanfaatan Folklor sebagai Pembelajatan Bermakna dalam Pembelajaran Bahasa dan Sastra Indonesia. Journal. Malang State University.

Suryaman, Maman. 2006. Pedoman Penulisan Buku Pelajaran Penjelasan Standar Mutu Buku Pelajaran Bahasa dan Sastra Indonesia. Jakarta: Pusat Perbukuan Departemen Pendidikan Nasional.

Syahridin, Atok and Muhammad Zen Ajrai. 2016. Menelusuri Jejak Sejarah Melayu di Labuhanbatu. Jakarta : Kinomedia.

Syarif, Raja Azman. 2016. Selayang Pandang Sejarah Labuhanbatu. Rantauprapat : Widya Puspita.

Thiagarajan, at el. 1974. Instructional Development for Training Teachers of Expectional Children: A Sourcebook. Washington, DC : Indiana University, Blomington, \& Center for Inovation in Teaching the Handdicapped.

Trianto. 2010. Mendesain Model Pembelajaran Inovatif-Progresif. Jakarta: Kencana Prenada Media Group.

Umami, Ulfa Riza dan Supriyadi. 2013. Pemanfaatan Nilai-Nilai Didaktik Nyanyian Permainan Anak-Anak Sapeken di Pulau Sapeken Kecamatan Sapeken Kabupaten Sumenep. Jurnal. Universitas Muhammadiyah Malang.

UU. Hamidy. 2005. Jagad Melayu dalam Lintas Budaya di Riau. Pekanbaru: Bilik Kreatif Press.

Warsita, Bambang. 2008. Teknologi Pembelajaran : Landasan dan Aplikasinya. Jakarta : Rineka Cipta.

Wawasanpendidikan.com. 2015. Modul: Pengertian, Karakteristik dan Tujuan Pembuatan serta Komponen-komponennya. Media. Books.

Yundiafi, Siti Zahra. 2010. Syair Saudagar Miskin. Jakarta : Pusat Bahasa Kementrian Pendidikan Nasional. 